J. Lake Sci.(湖泊科学), 2008, 20(3): 357-363

http://www.jlakes.org. E-mail: jlakes@niglas.ac.cn

(C)2008 by Journal of Lake Sciences

\title{
北京城市湖泊富营养化评价与分析*
}

\author{
荆红卫, 华 蕾, 孙成华, 郭 婧 \\ (北京市环境保护监测中心, 北京 100044)
}

摘 要: 根据 2006 年对北京市区不同功能重点湖泊水体进行的逐月监测, 采用综合营养状态指数法, 对湖泊富营养化现状进 行了评价. 结果表明, 水源湖泊目前处于中营养状态, 但在夏秋季由于温度和光照等气象条件的影响, 可接近轻富营养; 重要 景观湖泊处于轻一中度富营养; 一般景观湖泊处于中度一重度富营养状态. 湖泊富营养程度随季节变化明显: 盛夏和初秋形 成高峰, 冬、春季最低, 总磷、总氮含量与叶绿素 $\mathrm{a}$ 呈显著正相关关系, 尤其总磷与叶绿素 $\mathrm{a}$ 的相关性更加显著. 由于城市排 水管网不健全, 雨污分流不彻底, 暴雨期大量溢流生活污水直接向湖泊补水河道中排放; 湖泊补水沿线降雨径流产生的非点 源污染较严重; 加上污水处理厂再生水水质较差, 加重了补给湖泊富营养程度.

关键词: 北京; 城市湖泊; 富营养化

\section{Analysis on urban lakes' eutrophication status in Beijing}

JING Hongwei, HUA Lei, SUN Chenghua \& GUO Jing

(Beijing Municipal Environmental Monitoring Center, Beijing 100044, P.R.China)

\begin{abstract}
Referring to the different water body function, the survey of water quality was carried out on major urban lakes of Beijing monthly in 2006. According to TLI method, the state was evaluated on the basis of measurement result: lakes of drinking water source were mesotropher; lakes of major landscape water were light-middle eutropher; lakes of ordinary landscape water were middle-hyper eutropher. The eutrophic characteristics and its changing trend were analyzed. The causes were analyzed. The measures and suggestions were expounded on different water body function for improving water quality and reducing eutrophication.

Keywords: Beijing; urban lakes; eutrophication
\end{abstract}

北京市区共有大小湖泊 30 余个, 水面面积约 $7.3 \mathrm{~km}^{2}$. 最大的是昆明湖，面积 $1.94 \mathrm{~km}^{2}$. 湖泊水深一般 为 1.5-2m，属于城市小型浅水湖泊. 绝大部分湖泊与河道相通，汛期可防洪、排水，大的水域可调节周围 小气候. 2001 年夏季北京市城市河湖爆发了大面积的蓝藻水华. 2005 年 8 月底至 9 月初, 昆明湖又出现了较 严重的水华现象, 营养级别为中度富营养, 叶绿素 a 含量高达 $70.8 \mathrm{mg} / \mathrm{m}^{3}$, 浮游植物数量 $4108.28 \times 10^{4} \mathrm{cell} / \mathrm{s} / \mathrm{L}$, 给首都的生态环境和声誉带来了不良影响. 本文以 2006 年对市区重点湖泊进行的富营养化采样监测为 依据, 采用综合营养状态指数法, 对湖泊水体富营养化现状进行评价, 分析市区浅水湖泊富营养化特征 和变化规律, 研究其产生的原因, 提出有针对性的防治措施.

\section{1 监测与分析、评价方法}

\section{1 监测布点}

2006 年 4- 12 月 ( 1 月至 3 月结冰期除外)对北京市区 21 个重点湖泊开展了手工采样监测, 监测湖泊水 面面积达 $6.9 \mathrm{~km}^{2}$, 占市区湖泊总面积的 $95 \%$. 湖泊监测点位设置在湖心区和岸边区, 在 $0.5 \mathrm{~m}$ 左右深处采 集亚表层水样. 采样频次为每月一次, 采样时间为每月 1-10 日之间.

* 北京市科委项目(Z0005184040991)资助. 2007-09-03 收稿; 2007-12-28 收修改稿. 荆红卫, 女, 1966 年生, 高级工程师; E-mail: jinghongwei@bjmemc.com.cn. 



\section{2 监测项目与分析方法}

重点选取了与水体富营养化密切相关的监测项目: 水温、 $\mathrm{pH}$ 、透明度、溶解氧、高锰酸盐指数、五 日生化需氧量、氨氮、总磷、总氮、叶绿素 a 以及浮游植物群落分析.

叶绿素 $\mathrm{a}$ 的测定：取适量水样，倒人抽滤器中抽滤(滤膜孔径为 $0.45 \mu \mathrm{m}$ ); 将带有浮游植物的滤膜放人 冰箱中低温干燥 6-8h 后, 放人匀浆器中, 加人 $2-3 \mathrm{ml} 90 \%$ 丙酮溶液、少量碳酸美粉末, 充分研磨提取; 将 提取液置于离心管中, 离心 $10 \mathrm{~min}$, 将上清液倒人 $10 \mathrm{ml}$ 容量瓶中, 重复 $1-2$ 次, 直至沉淀物不含绿色, 最 后将上清液定容到 $10 \mathrm{ml}$, 摇匀. 在分光光度计上, 用 $1 \mathrm{~cm}$ 光程比色血, 分别读取 $750 \mathrm{~nm} 、 663 \mathrm{~nm} 、 645 \mathrm{~nm}$ 、 $630 \mathrm{~nm}$ 波长的吸光度, 并以 $90 \%$ 的丙酮作空白吸光度测定, 对样品吸光度进行校正.

浮游植物细胞分类与计数:

(1)定性(藻细胞分类): 样品用 25 号浮游生物网捞取, 在表层至 $0.5 \mathrm{~m}$ 深处以 $20-30 \mathrm{~cm} / \mathrm{s}$ 的速度作 $\infty$ 形 循回缓慢拖动约 1-3min, 装瓶带回实验室鉴定.

(2)定量(藻细胞计数): 采集水样 $1 \mathrm{~L}$ 加人 $15 \mathrm{ml}$ 鲁哥氏液固定, 倒人分液漏斗静置沉淀 $24 \mathrm{~h}$ 后, 用虹吸 管小心抽掉上清液, 余下 $20-25 \mathrm{ml}$ 沉淀物转人 $30 \mathrm{ml}$ 定量瓶中, 定容至 $30 \mathrm{ml}$; 将样品充分摇匀, 用移液管 吸取 $0.1 \mathrm{ml}$ 样品注人 $0.1 \mathrm{ml}$ 计数框内; 在 $10 \times 40$ 倍显微镜下计数 100 个视野, 每个样品计数两片取其平 均数, 每次计数的结果与其平均值之差应不大于 $15 \%$; 记录浮游生物的种类和个数, 最后将计数所得结 果换算成每升水中的浮游植物数量.

其它监测项目检测方法按照《地表水环境质量标准》(GB3838-2002)以及《水和废水监测分析方法》 (第四版)中要求的方法测定.

\section{3 评价方法}

目前我国湖泊富营养化评价的基本方法主要有营养状态指数法(卡尔森营养状态指数(TSI)、修正的营 养状态指数、综合营养状态指数 $(T L I)$ )、营养度指数法和评分法. 以上几种方法在实际工作中都被采用, 其 中营养度指数法计算步骤繁琐、耗时长, 不如综合营养指数法简便易行; 评分法在实际应用过程中, 受人为 因素的干扰较多, 影响结果的准确性. 因此, 本文选取综合营养状态指数法评价湖泊富营养化程度 ${ }^{[-2]}$.

评价项目选取了反映水体营养程度的主要指标: 叶绿素 a (Chl.a)、总磷 $(T P)$ 、总氮 $(T N)$ 、透明度 $(\mathrm{SD})$ 、 高镇酸盐指数 $\left(\mathrm{COD}_{\mathrm{Mn}}\right) 5$ 项. 综合营养状态指数为:

$$
T L I\left(\sum\right)=\sum_{j=1}^{m} W_{j} \times T L I(j)
$$

式中: $T L I\left(\sum\right)$ 为综合营养状态指数; $W_{j}$ 为第 $j$ 种参数的营养状态指数的相关权重; $T L I(j)$ 为第 $j$ 种参数的 营养状态指数.

以 Chl.a 作为基准参数, 则第 $j$ 种参数的归一化的相关权重计算公式为:

$$
W_{j}=r_{i j}^{2} / \sum_{j=1}^{m} r_{i j}^{2}
$$

式中: $r_{i j}$ 为第 $j$ 种参数与基准参数 Chl. a 的相关系数; $m$ 为评价参数的个数.

各项目营养状态指数计算公式为:

$$
\begin{aligned}
& \operatorname{TLI}(\mathrm{Chl} . \mathrm{a})=10(2.5+1.086 \operatorname{lnChl} . \mathrm{a}) ; \operatorname{TLI}(\mathrm{TP})=10(9.436+1.624 \operatorname{lnTP}) \\
& \operatorname{TLI}(\mathrm{TN})=10(5.453+1.694 \ln \mathrm{TN}) ; \operatorname{TLI}(\mathrm{SD})=10(5.118-1.94 \operatorname{lnSD}) \\
& \operatorname{TLI}\left(\mathrm{COD}_{\mathrm{Mn}}\right)=10(0.109+2.661 \operatorname{lnCOD})
\end{aligned}
$$

采用 $0-100$ 的一系列连续数字对湖泊营养状态进行分级: $T L I\left(\sum\right)<30$ 为贫营养; $30 \leqslant T L I\left(\sum\right) \leqslant 50$ 为中 营养; $T L I\left(\sum\right)>50$ 为富营养, 其中 $50<T L I\left(\sum\right) \leqslant 60$ 为轻度富营养, $60<T L I\left(\sum\right) \leqslant 70$ 为中度富营养, $T L I\left(\sum\right)>70$ 为重度富营养.

\section{2 结果与讨论}

\section{1 湖泊富营养化现状和特征}

2.1.1 湖泊富营养化总体状况 从 2006 年湖泊富营养化评价结果可以看出(表 1$)$, 监测的 21 个湖泊中, 除团城 
湖为 “中营养” 外, 其余 20 个湖泊均处于富营养状态, 其中 “轻度富营养” 湖泊 9 个, 占 $42.9 \%$; “中度富营 养” 湖泊 6 个, 占 $28.6 \%$; “重度富营养” 湖泊 5 个, 占 $23.8 \%$ (图 1). 可见, 北京城市湖泊富营养化较严重.

表 12006 年北京城市湖泊富营养化评价结果

Tab.1 Evaluation results of eutrophication on Beijing urban lakes in 2006

\begin{tabular}{|c|c|c|c|c|c|c|c|}
\hline 湖泊名称 & $\begin{array}{c}\text { 透明度 } \\
\text { 年均值(m) }\end{array}$ & $\begin{array}{l}\text { 高锰酸盐指数 } \\
\text { 年均值 }(\mathrm{mg} / \mathrm{L})\end{array}$ & $\begin{array}{c}\text { 总磷年均值 } \\
(\mathrm{mg} / \mathrm{L})\end{array}$ & $\begin{array}{c}\text { 总氮年均值 } \\
(\mathrm{mg} / \mathrm{L})\end{array}$ & $\begin{array}{c}\text { 叶绿素 a } \\
\text { 年均值 }\left(\mathrm{mg} / \mathrm{m}^{3}\right)\end{array}$ & $\begin{array}{l}\text { 综合营养 } \\
\text { 状态指数 }\end{array}$ & $\begin{array}{c}\text { 营养状态 } \\
\text { 级别 }\end{array}$ \\
\hline 团城湖 & 1.30 & 3.19 & 0.04 & 1.08 & 8.21 & 44.6 & 中营养 \\
\hline 昆明湖 & 0.87 & 4.91 & 0.06 & 1.06 & 15.75 & 51.4 & 轻度富营养 \\
\hline 西海 & 0.52 & 6.40 & 0.11 & 1.56 & 67.78 & 61.9 & 中度富营养 \\
\hline 后海 & 0.51 & 6.31 & 0.08 & 1.35 & 51.63 & 59.8 & 轻度富营养 \\
\hline 前海 & 0.61 & 6.09 & 0.09 & 1.38 & 56.76 & 59.6 & 轻度富营养 \\
\hline 北海 & 0.50 & 6.19 & 0.09 & 1.19 & 51.36 & 59.8 & 轻度富营养 \\
\hline 中海 & 0.57 & 7.22 & 0.07 & 1.12 & 46.55 & 58.6 & 轻度富营养 \\
\hline 南海 & 0.67 & 7.63 & 0.06 & 1.26 & 58.15 & 58.8 & 轻度富营养 \\
\hline 圆明园湖 & 0.84 & 8.49 & 0.07 & 0.92 & 19.86 & 55.0 & 轻度富营养 \\
\hline 玉渊潭湖 & 0.66 & 7.80 & 0.16 & 1.47 & 102.29 & 64.2 & 中度富营养 \\
\hline 八一湖 & 0.77 & 7.84 & 0.14 & 2.11 & 60.13 & 62.7 & 中度富营养 \\
\hline 紫竹院湖 & 0.53 & 7.35 & 0.13 & 1.50 & 61.93 & 62.7 & 中度富营养 \\
\hline 展览馆后湖 & 0.87 & 5.19 & 0.09 & 1.47 & 38.00 & 56.7 & 轻度富营养 \\
\hline 陶然亭湖 & 0.52 & 15.96 & 0.12 & 7.98 & 128.41 & 73.5 & 重度富营养 \\
\hline 龙潭湖 & 0.31 & 16.01 & 0.34 & 6.17 & 147.33 & 78.1 & 重度富营养 \\
\hline 青年湖 & 0.46 & 10.90 & 0.14 & 2.21 & 89.59 & 67.6 & 中度富营养 \\
\hline 红领巾湖 & 0.18 & 18.46 & 0.81 & 4.73 & 133.46 & 82.2 & 重度富营养 \\
\hline 柳荫公园湖 & 0.44 & 8.99 & 0.11 & 1.83 & 78.06 & 65.1 & 中度富营养 \\
\hline 筒子河 & 0.45 & 6.17 & 0.08 & 1.18 & 33.03 & 58.5 & 轻度富营养 \\
\hline 莲花池 & 0.26 & 12.80 & 0.12 & 2.58 & 111.39 & 71.0 & 重度富营养 \\
\hline 朝阳公园湖 & 0.19 & 16.02 & 0.32 & 3.32 & 103.98 & 76.9 & 重度富营养 \\
\hline
\end{tabular}

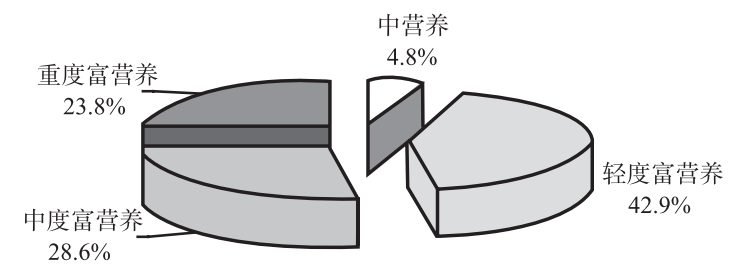

图 1 北京城市湖泊营养状态分布

Fig.1 The percent of different eutrophication grade on Beijing urban lakes

2.1.2 湖泊营养程度随季节变化规律 对 4-12 月湖泊各月营养程度进行统计可知(图 2), “中营养” 和 “轻 度富营养” 湖泊所占比例在冬季和春季较高, 冬季最高, 达 $66.7 \%$; 在夏季和秋季较低, 夏季 7 月最低, 只有 $14.3 \%$. “中度富营养” 和 “重度富营养” 湖泊所占比例在夏季和秋季较高, 夏季 7 月最高, 达 $85.7 \%$, 冬季最低, 为 $33.3 \%$. 表明湖泊富营养化程度随季节变化十分明显, 富营养化程度在盛夏和初秋形成高峰, 冬季、春季为全年最低. 


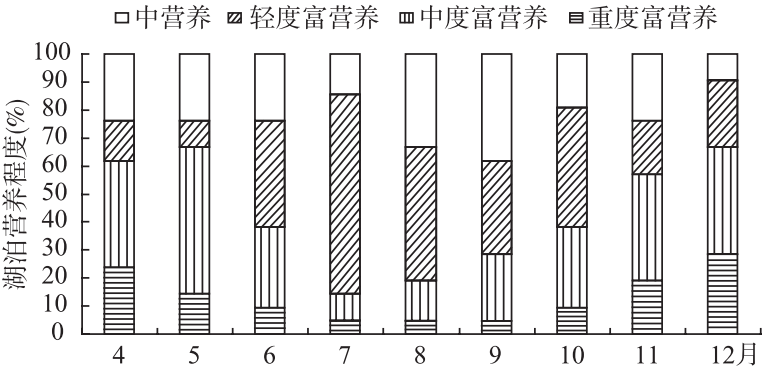

图 22006 年北京城市湖泊营养程度逐月变化情况

Fig.2 The monthly change of eutrophication on Beijing urban lakes in 2006
2.1.3 典型湖泊总氮、总磷含量与叶绿素 $\mathrm{a}$ 的相 关分析 氮磷是造成水体富营养化的主要元素. 根据典型湖泊团城湖、昆明湖、“六海”(西海、 后海、前海、北海、中海、南海)、龙潭湖总 磷、总氮含量与叶绿素 $\mathrm{a}$ 的相关分析可知(图 3), 总磷、总氮含量与叶绿素 $\mathrm{a}$ 呈显著正相关 关系, 并且总磷与叶绿素 $\mathrm{a}$ 的相关性更加显著. 氮磷比值 $(\mathrm{N} / \mathrm{P})$ 同样对藻类生长有重要影响, 当 $\mathrm{N} / \mathrm{P}$ 小于 7 时, 氮是可能的限制性营养盐, N/P 大于 7 时, 磷是可能的限制性营养盐. 日本湖 泊学家坂本曾经研究指出, 当湖水的总氮和总 磷浓度的比值在 10:1-25:1 的范围时, 藻类生

长与氮、磷浓度存在着直线相关关系 ${ }^{[3-6]}$. 北京城市湖泊氮磷浓度比基本在 10:1-21:1 之间, 处于藻类生 长最佳氮磷比值范围内.
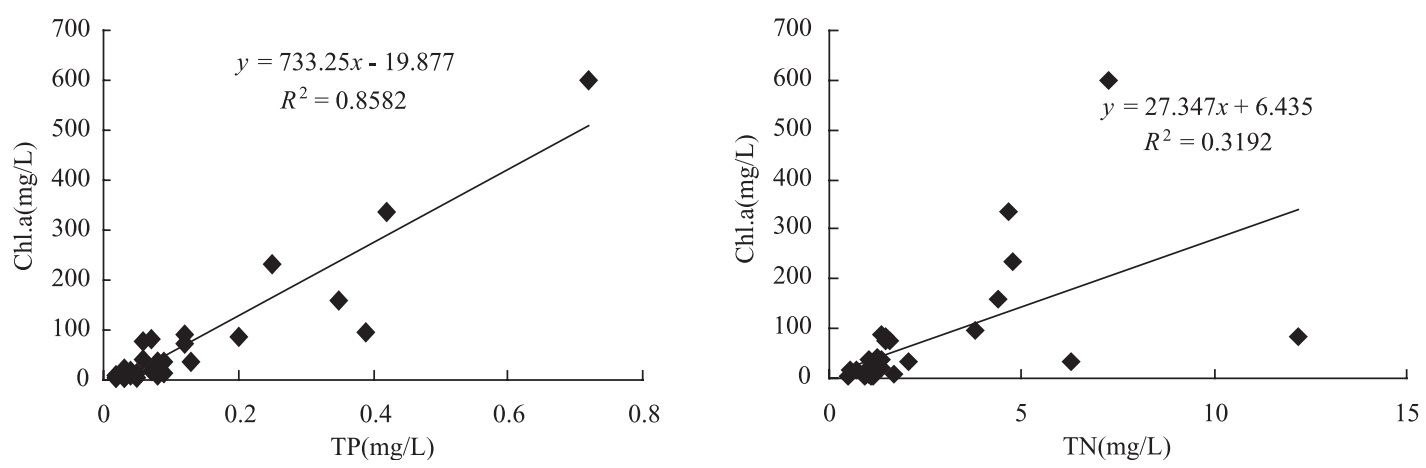

图 3 典型湖泊 2006 年总氮、总磷与叶绿素 a 相关关系

Fig.3 The correlation of TN, TP and Chlorophyll-a of typical lakes in 2006

\section{2 不同功能典型湖泊富营养化状况}

根据《北京市地表水环境功能区划方案》，北京市区湖泊按照功能分为三类：一是集中式饮用水源 地，水质目标为 II 类; 二是重要景观游览水域、一般鱼类保护区及游泳区，水质目标为 III 类; 三是人体 非直接接触的一般景观水域, 水质目标为 IV 类. 下面就不同功能选择重点湖泊分析其富营养化现状及其 特征.

2.2.1 水源湖泊的营养态势 团城湖是北京市唯一的一个以饮用水源功能为主的湖泊. 2006 年团城湖透明 度在 $1.2-1.5 \mathrm{~m}$, 高锰酸盐指数在 $2.2-3.9 \mathrm{mg} / \mathrm{L}$, 总磷在 $0.02-0.09 \mathrm{mg} / \mathrm{L}$, 总氮在 $0.51-1.68 \mathrm{mg} / \mathrm{L}$, 叶绿素 a 在 3.18-21.0mg $/ \mathrm{m}^{3}$ 之间; 各月综合营养状态指数在 39.1-49.8 之间变化, 全年平均为 44.6; 全年各月均处 于“中营养”状态(图 4); 营养指数峰值出现在 7 月, 已接近“轻度富营养”状态.

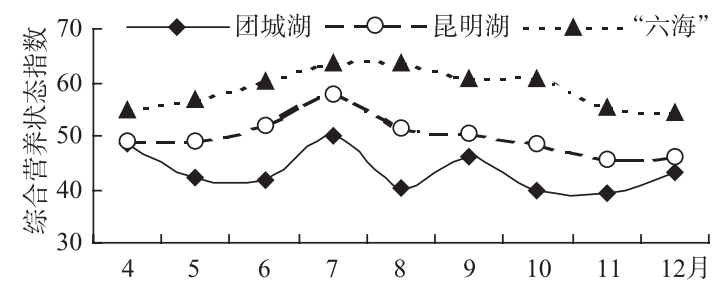

图 42006 年部分典型湖泊综合营养状态指数逐月变化趋势

Fig.4 The monthly changing trend of TLI on partial typical lakes in 2006 
浮游植物监测分析, 团城湖春季的优势种为金藻门锥囊藻, 为贫营养湖泊的优势种; 夏季的优势种 为栅藻、脆杆藻, 分别为中营养和富营养湖泊的代表种类, 浮游植物细胞数量为 $933.3 \times 10^{4} \mathrm{cell} / \mathrm{s} / \mathrm{L}$; 秋季的 优势种为微囊藻, 是形成水华的主要种类, 浮游植物细胞数量为 $4308.3 \times 10^{4} \mathrm{cells} / \mathrm{L}$. 因此, 团城湖浮游藻 类的群落结构: 春季以金藻为主, 夏季为蓝藻+绿藻型, 秋季为蓝藻型.

2.2.2 重要景观湖泊营养态势 (1) 昆明湖富营养化现状和特征: 昆明湖是北京市最大的湖泊, 水面面积为 $1.94 \mathrm{~km}^{2} .2006$ 年昆明湖水体透明度在 $0.6-1.1 \mathrm{~m}$, 高镇酸盐指数在 $3.8-5.6 \mathrm{mg} / \mathrm{L}$, 总磷在 $0.02-0.13 \mathrm{mg} / \mathrm{L}$, 总 氮在 $0.52-2.08 \mathrm{mg} / \mathrm{L}$, 叶绿素 a 在 7.16-34.37 mg $/ \mathrm{m}^{3}$ 之间. 综合营养状态指数在 45.4-57.9 之间变化(图 4), 全年平均为 51.4; 其中 6-9 月营养级别为 “轻度富营养” , 其它时间均为 “中营养”, 全年平均为 “轻 度富营养” 状态; 营养指数峰值出现在 7 月, 营养程度已接近 “中度富营养” .

浮游植物监测分析, 昆明湖春季的优势种为绿藻门的微小四角藻, 其中绿藻门占 $45.3 \%$, 硅藻门占 $16.5 \%$, 蓝藻门占 $14.0 \%$, 浮游植物细胞数量为 $2622.2 \times 10^{4} \mathrm{cells} / \mathrm{L}$; 夏秋两季的优势种均为微囊藻, 蓝藻门 占 $80 \%$ 以上, 夏、秋季浮游植物细胞数量分别为 $19685.2 \times 10^{4} \mathrm{cells} / \mathrm{L}$ 和 $33333.3 \times 10^{4} \mathrm{cells} / \mathrm{L}$. 因此, 昆明湖 浮游植物群落结构: 春季以绿藻为主, 夏秋两季均为蓝藻型; 从生物量来看, 秋季>夏季>春季.

(2) “六海” 富营养化现状和特征: “六海” 是京城的核心水系，总水面面积为 $1.24 \mathrm{~km}^{2} .2006$ 年 “六 海” 水体透明度在 $0.40-0.82 \mathrm{~m}$, 高锰酸盐指数在 $4.0-9.4 \mathrm{mg} / \mathrm{L}$ ，总磷在 $0.06-0.12 \mathrm{mg} / \mathrm{L}$ ，总氮在 $1.01-1.55 \mathrm{mg} / \mathrm{L}$, 叶绿素 a 在 23.46-89.17mg $/ \mathrm{m}^{3}$ 之间. 综合营养状态指数在 55.4-64.1 之间变化(图 4), 全 年平均为 59.8 , 营养指数峰值出现在 7 月和 8 月; 6-10 月营养级别为 “中度富营养” , 其它时间均为 “轻 度富营养” 状态.

浮游植物监测分析, “六海” 春季的优势种为绿藻门的微小四角藻和蓝藻门的微囊藻; 夏、秋季的优 势种均为蓝藻门易形成水华的主要种类一微囊藻和平裂藻. 4 月份蓝藻所占比例在 $43.2 \%-55.4 \%$, 绿藻在 $30.1 \%-36.3 \%$ 之间, 浮游植物细胞数量为 $9425.9 \times 10^{4} \mathrm{cells} / \mathrm{L} ; 7$ 月份蓝藻所占比例增大，在 $73.2 \%-89.4 \%$ 之 间, 绿藻所占比例为 $8.4 \%-25.2 \%$, 浮游植物细胞数量为 $32175.9 \times 10^{4} \mathrm{cells} / \mathrm{L} ; 9$ 月份蓝藻比例达 $81.5 \%-86.6 \%$, 浮游植物细胞数量达 $45865.7 \times 10^{4} \mathrm{cell} / \mathrm{s} / \mathrm{L}$. 因此, “六海”浮游植物群落结构: 春季为蓝藻十绿 藻型, 夏秋季均为蓝藻型; 从生物量来看, 秋季>夏季>春季.

综上所述，“六海”、昆明湖、团城湖营养程度排序依次为: “六海” >昆明湖>团城湖(图 4). 与 2005 年国内主要城市内湖营养程度相比，“六海” 比杭州西湖营养程度( $T L I=58.0)$ 高, 与济南大明湖 (TLI=60.0) 相当, 但比南京玄武湖 $(T L I=63.0)$ 、武汉东湖 $(T L I=63.0)$ 的营养程度低 ${ }^{[7]}$.

2.2.3 一般景观湖泊营养态势 2006 年监测的 21 个湖泊中, 有 8 个属于一般景观湖泊. 一般景观湖泊富营 养化程度处于 “中度一重度富营养” 状态, 其中有 5 个湖泊均处于 “重度富营养” 状态(表 1), 并且氮磷 含量明显高于饮用水源湖泊和重要景观湖泊(图 5). 按照营养程度排序: 一般景观湖泊>重要景观湖泊>水 源湖泊.
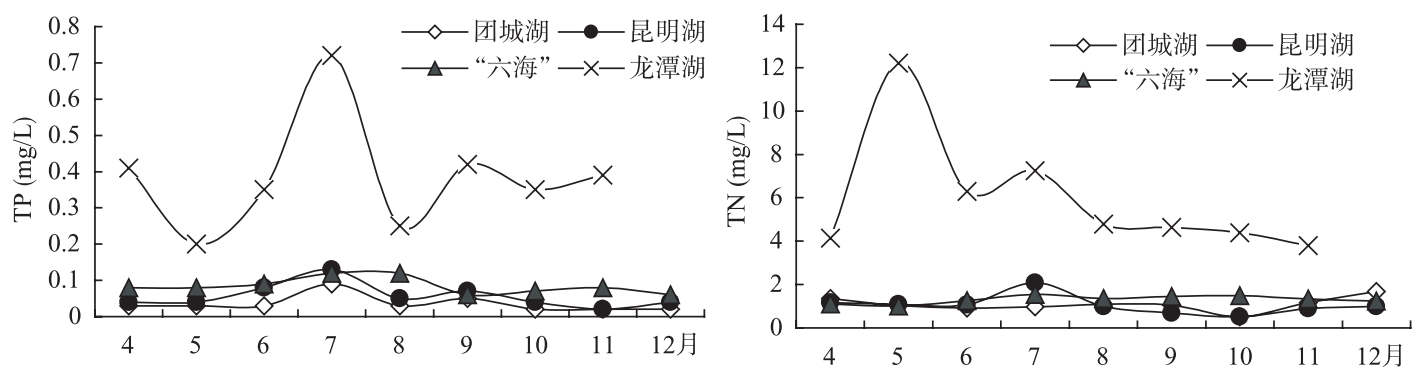

图 5 典型湖泊 2006 年总氮、总磷月变化曲线

Fig.5 TN and TP monthly changing curve of typical lakes in 2006

以龙潭湖为例, 龙潭湖位于龙潭公园内, 其水面面积 $35 \times 10^{4} \mathrm{~m}^{2}$, 水深 $1.5 \mathrm{~m} .2006$ 年监测结果显示, 龙 潭湖水体透明度在 $0.10-0.60 \mathrm{~m}$, 高锰酸盐指数在 $8.3-35.4 \mathrm{mg} / \mathrm{L}$, 总磷在 $0.20-0.72 \mathrm{mg} / \mathrm{L}$, 总氮在 
3.8-12.2mg/L, 叶绿素 a 在 34.7-600mg $/ \mathrm{m}^{3}$ 之间. 综合营养状态指数在 62.7-92.8 之间变化, 营养指数峰值 出现在 7 月; 营养程度除 4 月为 “中度富营养”外，其它时间均为 “重度富营养”。

\section{3 湖泊补给水源的水质分析}

截止 2006 年北京市区污水处理率已达到 90\%, 其中湖泊周边以及补水河道的工业污染源已全部搬 迁, 生活污水全部截留进人污水处理厂处理后出水排人城市下游河道，市区点源污染已基本得到控制. 因此，市区湖泊水质好坏主要受补水水源水质、水量的影响，同时又与在补水河道受到的污染有关. 湖泊 补水水源主要由三部分组成: 密云水库、官厅水库、污水处理厂再生水补给.

2.3.1 典型补水水源营养盐现状及其对湖泊水质的影响 密云水库是北京市重要饮用水源地, 水质长期 保持在 II 类, 2006 年总磷年均值为 $0.016 \mathrm{mg} / \mathrm{L}$, 总氮年均值为 $0.66 \mathrm{mg} / \mathrm{L}$; 官厅水库水质较差, 现状为 IV 类水质, 2006 年总磷年均值为 $0.081 \mathrm{mg} / \mathrm{L}$ ，总氮为 $1.57 \mathrm{mg} / \mathrm{L}$.

水体功能为饮用水源的团城湖: 团城湖为北京田村山自来水厂水源地, 由于其水源全部来自密云水 库, 且水源保护区管理严格, 输水沿线一京密引水渠基本无点源、面源污染物排人, 因此团城湖水质良好, 水体营养盐含量低，目前未达到富营养程度.

水体功能为重要景观的湖泊: 重要景观湖泊补给水源来自密云水库和官厅水库联合供水. 一方面官 厅水库本身水质较差, 另一方面密云、官厅之水流经补水河流时，水质又有不同程度下降，对景观湖泊水 质有较大影响. 所以, 重要景观湖泊昆明湖、“六海” 等营养程度明显高于团城湖, 处于 “轻度富营养” — “中度富营养” 状态. 例如: “六海” 由密云水库补水时, 补水路线为: 密云水库一京密引水渠一昆玉 河一长河一 “六海”; 由官厅水库补水时, 路线为官厅水库一永定河引水渠一昆玉河一长河一 “六海”. 监 测结果显示, 密云水库的 II 类水质, 通过昆玉河、长河、永定河引水渠等补水河流时，在暴雨季节水质下 降为 $\mathrm{V}$ 类一劣 $\mathrm{V}$ 类，其中昆玉河、永定河引水渠丰水期总磷、总氮比枯水期升高 5.6-6.0 倍和 2.6-2.8 倍 (图 6).
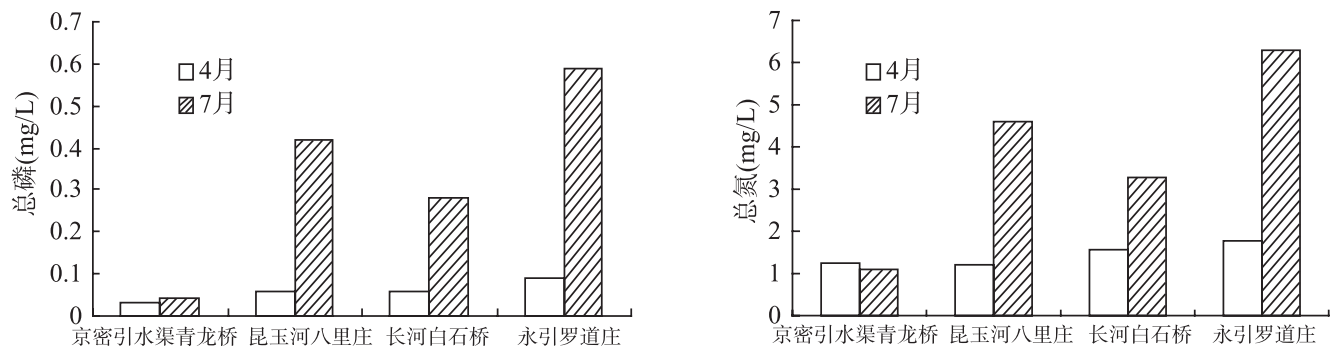

图 62006 年补水河流枯、丰水期营养盐含量变化对比

Fig.6 The comparison of nutrient salts content change on filling water river at low-water season and high-water season in 2006

密云、官厅之水流经补水河流时，水质下降的原因主要有以下三方面:

(1)暴雨期溢流生活污水入河影响: 目前北京市区污水处理率虽然较高, 但由于城市排水管网不健全, 雨污分流不彻底, 在湖泊补水河道仍然存在暴雨期大量溢流生活污水人河现象. 根据 1999 年北京市水务 部门进行的人河排污口调查, 昆玉河有 12 个雨污合流口，长河有 11 个雨污合流口，永定河引水渠有 28 个雨污口, 为减少雨污合流管道向河湖排污, 采取了两种补救措施, 一种是挡堰式污水截留, 一种是槽 式污水截留, 但这两种补救措施在降雨超过 $15 \mathrm{~mm}$ 时, 雨水就会携带着大量溢流生活污水直接排人河流, 对河流水质产生了较大影响.

(2)非点源污染影响：暴雨期重要景观湖泊不仅要面临补水河道溢流污水人河的问题, 同时还要承受 降雨形成的地表径流污染的影响. 研究表明降雨径流中固体悬浮物和营养盐浓度极高, 大量流人河湖中, 对湖泊水质产生了极大影响 ${ }^{[8]}$.

(3)补给水量较少: 1999 年以来北京市连续干旱, 水资源严重短缺, 引人城市河湖的水量减少, 根据 
预测规划市区河湖环境需水量为 $2 \times 10^{8}-3 \times 10^{8} \mathrm{~m}^{3} /$ 年，但“十五”期间每年实际向城市河湖供水仅 $0.6 \times 10^{8}-0.8 \times 10^{8} \mathrm{~m}^{3}$, 从而不能满足城市河湖用水要求; 补给的水量仅能够维持水体的蒸发与渗漏, 水 体自净能力明显减弱, 水质下降.

2.3.2 污水处理厂再生水补给湖泊的水质问题 由于水资源严重短缺，目前一般景观湖泊补水主要依靠污 水处理厂的再生水补给, 如: 龙潭湖、陶然亭湖、红领巾湖、朝阳公园湖等, 其水源均来自高碑店污水处 理厂的再生水，再生水已成为北京的第二水资源. 《城市污水再生利用-景观环境用水水质》(GB/ T18921 -2002)标准规定了将再生水回用于景观环境时的水质要求, 但存在的问题是: 规定的再生水景观水质标 准与地表水景观水质标准之间有较大差距, 再生水中氨氮、总磷和总氮水质标准值是地表水景观水体 IV 类标准的 3.3 倍、 5 倍和 10 倍.

因此，当再生水补人一般景观湖泊时，由于再生水氮、磷含量高，使得一般景观湖泊水体氮、磷含量 也明显增高，富营养化程度加重. 例如, 2006 年 5 月对陶然亭湖以及再生水补水口进行总氮指标的同步监 测, 补水口总氮含量为 $31.2 \mathrm{mg} / \mathrm{L}$, 湖水总氮为 $16.8 \mathrm{mg} / \mathrm{L} .2006$ 年以再生水为水源的龙潭湖、陶然亭湖、 红领巾湖、朝阳公园湖等总磷年均值在 $0.12-0.81 \mathrm{mg} / \mathrm{L}$ 之间，总氮年均值在 $3.32-7.98 \mathrm{mg} / \mathrm{L}$ 之间，营养状 态全部为 “重度富营养”。

\section{3 建议}

(1) 建议进一步加大对雨污合流排水管网的改造, 解决暴雨期溢流生活污水直接向城市河湖排放的 问题; 全面开展城市地表径流非点源污染调查和研究, 掌握城市地表径流污染特征和排放规律, 研究非 点源污染的控制途径，制定相应的法规与政策，将城市径流污染控制纳人法制轨道.

(2) 污水处理厂再生水水质较差, 加重了补给湖泊富营养程度. 建议进一步提高污水处理厂再生水 出水的排放标准, 加大对氮磷的处理和控制, 特别是控制磷的浓度是降低富营养化风险的重要途径; 同 时再生水出水经湿地处理, 水质达到地表水环境 IV 类标准要求后再人湖 ${ }^{[9]}$.

(3) 生态补水严重不足. 建议对湖泊水体实施生态修复工程的同时, 加大向重点景观湖泊供应清洁 水, 保证其最小生态需水量.

\section{4 参考文献}

[1] 金相灿，屠清瑛主编. 湖泊富营养化调查规范. 北京: 中国环境科学出版社, 1990: 286-302.

[2] 王明翠, 刘雪芹, 张建辉. 湖泊富营养化评价方法及分级标准. 中国环境监测, 2002, 18(5): 47-49.

[3] Vollenweider RA. Elemental and biochemical composition of plankton biomass; some comments and explorations. Arch Hydrobiol, 1985, 105: 11-29.

[4] 日本水产学会. 水圈的富营养化与水产增殖. 韩书文, 鲁守范译. 北京: 农业出版社, 1986: 1-19.

[5] 陈 琼. 氮、磷对水华发生的影响. 生物学通报, 2006, 41(5): 12-14.

[6] 秦伯强, 杨柳燕, 陈非洲等. 湖泊富营养化发生机制与控制技术及其应用.科学通报, 2006, 51(16): 1857-1866.

[7] 国家环境保护总局. 2005 年中国环境状况公报. 2006.

[8] 车 伍, 黄 宇, 李俊奇. 北京城区河湖水系治理中的问题与建议. 环境污染与防治, 2005, 27(8): 593-596.

[9] 倪福勋, 曾思育, 张天柱. 奥运湖不同补水方案营养状态趋势分析. 四川环境, 2006, 25(14): 82-86. 